\title{
Thoughts on Deepening the Cultural Cooperation Between Russia and Heilongjiang Province*
}

\author{
Chunyan Li \\ College of Culture and Tourism \\ Heihe University \\ Heihe, China 164300
}

\author{
Chuanhuai Peng \\ College of Culture and Tourism \\ Heihe University \\ Heihe, China 164300
}

\begin{abstract}
In recent years, Sino-Russian comprehensive strategic partnership has been deepened, and pragmatic cooperation in various fields has been continuously strengthened, which has promoted the continuous improvement of cultural cooperation between Russia and Heilongjiang Province. The cultural cooperation between Russia and Heilongjiang Province is the leader of Sino-Russian cultural cooperation. Heilongjiang Province has a unique geographical advantage for Sino-Russian cultural cooperation. Under the favorable background of the great development and prosperity of Chinese culture, the cooperation should be in line with the needs of the development of the new situation. Heilongjiang Province should give full play to the regional advantages, upgrade the cultural cooperation to the national strategic level, deepen the comprehensive strategic cooperative partnership between China and Russia, and promote the deepening of cooperation in various fields. It has far-reaching implications.
\end{abstract}

Keywords-Heilongïing province; Russia; cultural cooperation; national strategy

\section{INTRODUCTION}

In recent years, with the continuous development of Sino-Russian cultural cooperation, Heilongjiang Province has continuously deepened its humanities exchanges and cooperation with Russia, deepening and broadening the connotation of Sino-Russian "comprehensive strategic partnership of cooperation". Based on this, Heilongjiang Province has fully utilized the geographical advantages of neighboring Russia, actively built a platform for humanities exchanges and cooperation with Russia, and achieved fruitful results in Sino-Russian humanities exchanges and cooperation. The political foundation of Sino-Russian cooperation has been continuously consolidated. The economic and trade cooperation has been continuously developed. And the culture has been continuously integrated.

*Fund Project: It is the phased objectives of the Philosophy and Social Science Research Project of Heilongjiang Province in 2018-"Research on the Status quo and Function of Sino-Russian Humanities Exchange in Heilongjiang Basin" (18GJE484).

\section{THE PRACTICAL SigNIFICANCE OF DEEPENING THE CULTURAL COOPERATION BETWEEN RUSSIA AND HEILONGJIANG PROVINCE}

It is conducive to enhancing Sino-Russian political mutual trust. In recent years, as a leader in humanities cooperation with Russia, Heilongjiang province has deepened the exchanges and cooperation with Russia in the field of humanities. This has deepened the understanding of the Chinese and Russian peoples on the long history, splendid culture and economic and social development achievements. It has laid a solid foundation for the healthy and orderly development of the relationship. The peace thoughts of Sino-Russia friendship from generation to generation deeply roots in the hearts of the people. And it has consolidated the political foundation for the Sino-Russian strategic partnership of cooperation.

It will promote the development of Sino-Russian economic and trade cooperation. The humanities cooperation between Russia and Heilongjiang Province will rise to be a national strategy, which is an important requirement for "strengthening humanities exchanges and promoting common prosperity". Without humanistic exchanges as the basis, economic and trade cooperation will not last long. Heilongjiang Province actively participated in and cosponsored Sino-Russian "National Year", "Tourism Year", "Cultural Exhibition", "Russian Style Competition", "Art Fair", "Sino-Russia Expo" and other activities to promote the integration of economic and trade cooperation with science and technology and humanities cooperation. It has deepened the mutual understanding and traditional friendship between the two parties and promoted the in-depth development of bilateral economic and trade cooperation.

It will promote the integration of Chinese and Russian different national cultures and achieve cultural identity. The successive leaders of China and Russia attach great importance to the cultural integration between different ethnic groups. It has promoted humanities exchanges and cooperation from a political height, consolidated the social foundation of Sino-Russian friendship, and achieved cultural mutual recognition. In recent years, Heilongjiang Province has actively established a platform for humanities cooperation with Russia, and has made great achievements in cultural exchanges, art exchanges, educational exchanges, 
youth exchanges, sports exchanges, archives exchanges, tourism exchanges, and legal exchanges. The two parties have deepened the friendship and enhanced the understanding in humanities exchanges and cooperation. It has played an irreplaceable role in establishing a good national image.

\section{HeILONGJiang Province DeEPENS THE} ADVANTAGES OF SINO-RUSSIAN HUMANITIES COOPERATION

Heilongjiang Province has obvious advantages in humanities cooperation with Russia. The author believes that Heilongjiang Province has three major advantages in SinoRussian humanities cooperation: location advantage, port advantage, and talent advantage.

The location advantage is obvious. There is more than 4,300 kilometers of borderline between Heilongjiang Province and Russia. It is the province with the largest number of borderline between China and Russia. Heilongjiang Province has corresponded to political and cultural centers such as Khabarovsk and Blagoveshchensk in the Russian Far East area. It has unique location advantage in regional humanities cooperation.

The port location advantage is obvious. There are 18 national first- and second-class ports in Heilongjiang Province. The docking of the ports not only promotes the prosperity of Sino-Russian trade, but also promotes the indepth development of humanities cooperation between the two countries. Such unique advantages are also difficult to obtain in other provinces.

The talent advantage is obvious. With the Sino-Russian exchanges and cooperation, Heilongjiang Province has cultivated a large number of Sino-Russian compound talents, which have made great contributions to the development of various fields in China and Russia. Taking Heihe College as an example, Heihe College took full advantage of SinoRussian education exchanges and actively carried out the training of Russian talents. There are more than 1,200 students in the school. At present, the Russian major of Heihe College has become a professional construction point of national characteristics, and Russian language and literature has become a provincial key construction discipline.

Heilongjiang Province has outstanding characteristics in Sino-Russian humanistic cooperation, with fruitful results and remarkable effects. In recent years, Heilongjiang Province has made full use of the three major advantages, actively established a cooperation platform, and continuously strengthened the cooperation between Chinese and Russian officials, businessmen, and people, and achieved fruitful results. For example, Jixi City held the Sino-Russian Cultural Exchange Week in 2004. Harbin Sino-Russian Folk Culture Exchange Center was constructed in Nangang District in 2006, and its establishment established a new important platform for the development of Sino-Russian folk cultural exchange activities. The "Harbin-Songbei Sun Island Russian Oil Painting Art Gallery" was held in Harbin in 2007. Heihe City held the "Heilongjiang Sino-Russian Culture Exhibition" in 2010. Harbin held the first "Hanan Industrial New City Cup" Sino-Russian Youth Cultural
Exchange Week and the 4th Sino-Russian Youth Partner League Tournament in 2011. Dongning County held the Treasure jade Culture Festival in 2012. Harbin held the SinoRussian Expo and the Cultural Fair in 2014. The Second Harbin Sino-Russian Culture and Art Exchange Week were held in 2017. The Suifenhe Sino-Russian oil painting art exchange exhibition was held in 2018. All of these activities have enhanced the awareness and participation of the Chinese and Russian people in humanities cooperation. "The friendship among the countries lies in the people's friendship". The Sino-Russian cultural exchange activities have deepened mutual understanding between the people of the two countries, and also built an important platform for the people of China and Russia to communicate with each other. Sino-Russian cultural activities are not only a platform for the two peoples to gather together, but also an intersection point between culture and tradition. It is also the best interpretation of true friendship.

\section{PRoBlems In HeILONGJIANG PROVINCE'S DEEPENING OF HUMANITIES COOPERATION WITH RUSSIA}

\section{A. There Is an Imbalance in the Cultural Exchanges Between China and Russia}

In recent years, Heilongjiang Province's official cultural exchanges with Russia have achieved normalization and scale, and the folk cultural exchanges with Russia have achieved leap-forward development, forming a situation in which the government and the folk have cultural exchanges with Russia. However, the official cultural exchanges and the folk cultural exchanges between Heilongjiang Province and Russia only coexisted, and they did not develop in parallel. There was a significant imbalance between the official cultural exchanges and the folk cultural exchanges. First, the official guidance and promotion for the folk cultural exchanges with Russia is not enough. In recent years, the government has attached great importance to the cultural exchanges with Russia, and has held large-scale SinoRussian cultural exchange activities for many times. This has played a good role in demonstration. However, the official guidance and the promotion for non-governmental organizations participating in the cultural exchanges with Russia are not enough. The activities basically stayed at the official level, and the participation of non-governmental organizations was not wide enough, which affected the export of folk culture to Russia. Second, there are certain problems in the non-governmental organization. The nongovernmental organization lacks theoretical intervention in Russian cultural exchanges. It is urgent to systematically summarize and theoretically improve its experience and lessons. The non-governmental organizations pursue economic benefits, and there is disorderly competition. The non-governmental organization personnel flow frequently and the talents are not enough, lacking of stability in the cultural exchanges with Russia. The degree of intensiveness of folk cultural exchanges with Russia is still relatively low, and the level of non-governmental integration of Russian cultural exchanges is not high. 


\section{B. Lacking Compound Talents for the Cultural Exchanges with Russia}

It goes without saying that Russian is an important tool and carrier for cultural exchanges with Russia. And it is said that Russian is the key to becoming a compound talent for cultural exchanges with Russia. Heilongjiang Province is a province with many Russian talents. It is also the most important Russian talent training base in China. Many universities and vocational colleges in the province have specialized Russian language departments or Russian majors. The unique advantage of Russian professionals has greatly promoted the development of cultural exchanges between Russia and Heilongjiang province. However, in recent years, the Russian language talents in Heilongjiang province have been in a state of temporary shortage. The size of Russian students has shrunk. Many junior high Russian classes have been cut down. Even some secondary schools in the port cities have reduced the number of Russian admissions. The scarcity of Russian professionals will directly affect the cultivation of Russian cultural exchange compound talents. If this state continues, Heilongjiang Province will gradually lose its advantage of Russian talents, which will inevitably affect the development of Russian cultural exchanges. And it will can't meet the development needs to be

\section{The Breadth and Depth of Russian Cultural Exchanges Need to Be Improved}

In recent years, Heilongjiang Province has made great progress in cultural exchanges with Russia and made certain contributions to the development of China's foreign regional culture. However, it is not difficult to find out that the breadth and depth of cultural exchanges with Russia need to be improved. In terms of breadth, on the one hand, most of the cultural exchange activities between Russia and Heilongjiang Province are concentrated in the provincial capital Harbin or border port cities. Other cities in the province have little or less opportunities to hold cultural exchange activities with Russia. Even if there have the opportunities, the level of exchange activities is not high, the scale is small, and the impact is not far-reaching. On the other hand, the content of Heilongjiang province's cultural exchanges with Russia needs to be broadened. At present, Heilongjiang Province has made certain achievements in the fields of music, sports, art and education in the cultural exchanges with Russia. However, the two parties still have a lot of room for improvement in book exchanges and interlibrary exchanges. The two parties have not had substantive cooperation. In terms of depth, Heilongjiang Province lacks theoretical support for the cultural exchanges with Russia. On the one hand, in recent years, Heilongjiang Province has held many large-scale cultural exchange activities with Russia, such as the Sino-Russian cultural exhibition in Heilongjiang province. The event was hosted by the Ministry of Culture, and the Cultural Department of Heilongjiang Province. It is a national-level large-scale cultural exchange activity with Russia. However, there is no cultural forum in the exchange activities, and there is no theoretical guidance for the communication activities. On the other hand, Heilongjiang's share of cultural trade is still insufficient. The ability to promote "going out" of cultural enterprises and cultural products needs to be improved. Therefore, to innovate and broaden the methods and channels for cultural "going out" requires us to conduct key research.

\section{Suggestion For DeEPEnING THE HuMANities COOPERATION BETWEEN RUSSIA AND HEILONGJIANG PROVINCE}

In recent years, the importance of Heilongjiang Province's humanities exchanges and cooperation with Russia has become increasingly prominent. In order to speed up the exchange of humanities and cooperation between Russia and Heilongjiang Province, the province's cultural exchanges and cooperation with Russia have always been in the leading position, and the author has proposed the following countermeasures for the healthy development of Sino-Russian relations.

\section{A. Giving Play to the Regional Advantages in the Exchanges with Russia, and Steadily Enhancing the Humanities Cooperation}

Humanities cooperation is a reflection of political and economic cooperation. The closer the humanities cooperation is, the more prosperous economic cooperation will be. Otherwise, it is the same. Therefore, the state should take advantage of Heilongjiang's economic trade with Russia to promote humanities cooperation. By deepening economic and trade cooperation, vigorously developing cultural industries, relying on Heilongjiang tourism resources, Heilongjiang province can build tourism brands, increase the cultural content of relevant industries, extend the cultural industry chain, and increase added value, thus promoting the economic development of Heilongjiang with culture as a link.

\section{B. Actively Building a Platform to Promote Humanities Cooperation with Russia}

The official cultural exchanges and the folk cultural exchanges have coexisted, however, they have not been equal. This shows that there is still much room for improvement in the humanities exchanges and cooperation between Russia and Heilongjiang Province. Therefore, we must adhere to the principle of coexistence and equal emphasis on official humanities exchanges and cooperation and folk cultural exchanges and cooperation, provide official support and policy support for humanities exchanges and cooperation between the two parties, vigorously carry out non-governmental exchanges and cooperation with Russia, actively support non-governmental organizations to go out and continuously expand the trade with Russia. Specifically, the first is to continue to strengthen the official exchanges between Heilongjiang Province and Russia, and provide policy support for humanities exchanges and cooperation between the two parties. The second is to focus on the guidance and promotion of folk organization. That is to say, in the official exchanges and humanities cooperation with Russia, Heilongjiang province should absorb many localities to participate in the exchanges, and folk organization should be strictly required by official standards. The third is to strengthen the theoretical intervention of the folk humanities exchanges and cooperation with Russia, and enhance the 
intercultural communication ability. The fourth is to enhance the cultural connotation of the folk cultural exchanges and cooperation with Russia, and enrich the content of the folk cultural exchanges and cooperation with Russia. The fifth is to integrate Russian humanities exchange and cooperation resources, make the classification management, and enhance communication space.

\section{Strengthening the Cultivation of Sino-Russian Compound Talents and Promoting Cultural Exchanges with Russia}

Russian is an important carrier for Sino-Russian humanities cooperation. Heilongjiang Province is a large province where Chinese and Russian compound talents gather. It is also the most important Sino-Russian compound talent training base in China. Strengthening the cultivation of Sino-Russian compound talents is the need of economic and social development of Heilongjiang Province. It is also an inevitable choice to promote Heilongjiang Province's humanities exchanges and cooperation with Russia. Therefore, Heilongjiang Province should make full use of the advantages of Russian talents, increase the training of SinoRussian compound talents, and provide talent reserves for Russian humanities exchanges and cooperation. The first is to give full play to Heilongjiang province's unique advantages in exchanges and cooperation with Russia education, and cultivate compound Russian talents through multiple channels. The second is to improve the curriculum and cultivate practical Russian talents through the Russian+professional training model. The third is to give full play to the favorable conditions for the colleges and universities in Heilongjiang province to jointly run schools with Russia, dispatch the teachers and students, strengthen mutual communication and exchanges, and feel Russian culture. The fourth is to further broaden students' knowledge and enhance the language communication skills.

\section{Broadening and Deepening Sino-Russian Cultural Exchanges}

Heilongjiang province should build a platform, effectively integrate regional resources, make full use of the geographical advantages of border ports and cities for humanities exchanges and cooperation, and use border cities to drive other cities in the province to achieve simultaneous development of humanities exchanges and cooperation between the border and inland cities. The both parties should strengthen Sino-Russian book exchanges and inter-library exchanges, promote the substantive work of book and interlibrary exchanges between the two parties, and further enrich the content of humanities exchanges and cooperation. Heilongjiang province should create a cultural forum on humanities exchanges and cooperation with Russia, and establish a special cultural forum for regular exchanges and cooperation activities with Russia. It can provide academic theories for a series of Sino-Russian humanities exchanges and cooperation. Also, it can innovate the methods for SinoRussian humanities exchanges and cooperation, expand the proportion of cultural trade with Russia, promote cultural exchanges through bilateral cultural trade, and promote cultural trade through humanities exchanges and cooperation.

\section{CONCLUSION}

With the regional advantages and humanities cooperation, economic and trade cooperation with Russia is an important carrier for the expansion of Heilongjiang Province along the border, and an important part of accelerating the construction of a comprehensive open system. With the implementation of the two plans of the "Development and Open Planning of the Northeast of Inner Mongolia and Heilongjiang Province" and the "Social and Economic Development Plan of the Far East and Baikal Region 2025", the cooperation between China and Russia is expanding from general cooperation to industrial cooperation, forming a cross-border industrial chain, and then stepping out of the road of industry enriching the people.

\section{REFERENCES}

[1] To play a leading role in the cultural exchange with Russia and promote the economic development of Heilongjiang procince (http://www.suifenhe.gov.cn)

[2] The unique role and geographical advantage of Heilongjiang province in Sino-Russian cultural exchanges (http://www.noelworld.com/channel/newsinfo/infoid/834.html).

[3] Li Yanan. On Humanities Exchanges and Cooperation in the Development Process of Sino-Russian Relations [J]. Northeast Asia Forum, 2011 (6)

[4] Guo Li et al. History and reality of Sino-Russian humanities cooperation [M]. Heilongjiang University Press, 2013.

[5] Huang Dingtian. History of Sino-Russian Cultural Relations [M] Changchun Publishing House, 2011.

[6] Liu Bo. Strengthening cultural exchanges and cooperation between Heilongjiang province and Russia [J]. Siberian Studies, 2005. 5. 